(c) American Dairy Science Association, 2003.

\title{
Effects of pH, Temperature, Supplementation with Whey Protein Concentrate, and Adjunct Cultures on the Production of Exopolysaccharides by Streptococcus thermophilus 1275
}

\author{
B. Zisu and N. P. Shah \\ School of Molecular Sciences, \\ Victoria University, Werribee Campus, \\ PO Box 14428, Melbourne City Mail Center, \\ Victoria 8001, Australia
}

\section{ABSTRACT}

Effects of $\mathrm{pH}$, temperature, supplementation with whey protein concentrate (WPC), and non-EPS culture on the exopolysaccharide (EPS) production by Streptococcus thermophilus 1275 were studied. The organism was grown in $10 \%$ reconstituted skim milk (RSM) in a Biostat B fermenter for $24 \mathrm{~h}$ at various $\mathrm{pH}(4.5,5.5$ and 6.5) and temperatures (30, 37, 40, and $42^{\circ} \mathrm{C}$ ), and supplementation with WPC 392, and non-EPS producing $S$. thermophilus 1303 and the amount of EPS produced were determined. Bacterial counts were enumerated and the concentrations of lactic acid, lactose, glucose, and galactose were also determined. A maximum of $406 \mathrm{mg} / \mathrm{L}$ of EPS was produced in RSM at $37^{\circ} \mathrm{C}$ after $24 \mathrm{~h}$ of fermentation at $\mathrm{pH} 4.08$ when the $\mathrm{pH}$ was not controlled. A pH of 5.5 and temperature of $40^{\circ} \mathrm{C}$ were found to be optimal for EPS production by $S$. thermophilus 1275 , yielding 458 $\mathrm{mg} / \mathrm{L}$. The EPS production increased when RSM was supplemented with WPC 392. At optimum $\mathrm{pH}$ and at $37^{\circ} \mathrm{C}$ with WPC supplementation, the level of EPS increased to $1029 \mathrm{mg} / \mathrm{L}$. Co-culturing $S$. thermophilus 1275 with non-EPS S. thermophilus 1303 increased EPS production at $37^{\circ} \mathrm{C}$ and $\mathrm{pH} 5.5$ to $832 \mathrm{mg} / \mathrm{L}$. High temperature $\left(42^{\circ} \mathrm{C}\right)$ reduced the amount of EPS production, and EPS production ceased at $\mathrm{pH} 4.5$ when maintained constantly at this $\mathrm{pH}$. The level of lactose utilization and lactic acid production depended on growth conditions of the organism. No glucose was detected, while galactose was found to accumulate in the medium.

(Key words: exopolysaccharide, Streptococcus thermophilus 1275, whey protein concentrate, adjunct culture)

Received April 24, 2003

Accpeted August 7, 2003

Corresponding Author: N. P. Shah; e-mail: Nagendra.Shah@vu. edu.au.

\begin{abstract}
Abbreviation key: EPS = exopolysaccharides, LAB = lactic acid bacteria, $\mathbf{R S M}=$ reconstituted skim milk, SMP $=$ skim milk powder, $\mathbf{W P C}=$ whey protein concentrate.
\end{abstract}

\section{INTRODUCTION}

Polysaccharides are used extensively by the food industry to thicken, gel, emulsify, and stabilize suspensions. Most polysaccharides are of plant and algae origins, with the exception of a few microbial derived exopolysaccharides (EPS), chiefly xanthan gum and gellan (Coultate, 1996).

Many food grade microorganisms have the ability to synthesize EPS and the potential to exploit such bacteria has recently been recognized. Exopolysaccharide-producing lactic acid bacteria (LAB) are commonly used, particularly in the dairy industry, for the manufacture of fermented milks. Exopolysaccharide plays a key role in the rheological behavior, mouthfeel, and texture of fermented products without the use of additives.

Microorganisms produce EPS in two distinct forms: ropy EPS or loose slime that is excreted into the surroundings, and capsular EPS that remain adhered to the cell surface creating a discrete covering (Broadbent et al., 2003). Many capsular strains of bacteria have been shown to produce loose slime in addition to capsules (Duguid, 1951; Cerning, 1990a; Broadbent et al., 2003). The term EPS is generally used to describe all forms of bacterial polysaccharides found outside the cell wall. The role of EPS is not clearly defined. Capsular EPS play a part in cell protection from the immediate environment when conditions are unfavorable (Cerning, 1990a). Microbial EPS are extracellular, long-chained, and high molecular mass polymers (branched, containing $\alpha$ - and $\beta$-linkages) that are either homopolysaccharide or heteropolysaccharide in nature (De Vuyst and Degeest, 1999). The carbohydrate composition of EPS is unique to different strains of bacteria and may vary depending on the growth 
conditions; however, glucose and galactose in particular are frequently detected in the EPS composition of many bacterial species (Cerning, 1990a; Ariga et al., 1992; Roberts et al., 1995; Bouzar et al., 1996; Castern et al., 1998; Uemura et al., 1998; De Vuyst and Degeest, 1999; Knoshaug et al., 2000).

The amount and the composition of the EPS produced by thermophillic LAB are strongly influenced by culture and fermentation conditions and are growth associated. Production of EPS is dependent on the temperature and $\mathrm{pH}$ of the medium as well as composition of the medium in terms of carbon and nitrogen source, and mineral and vitamin contents (De Vuyst et al., 1998; Gamar-Nourani et al., 1998; Grobben et al., 2000; Gorret et al., 2001). The effect of temperature and $\mathrm{pH}$ on EPS production is highly variable and is dependent on the strain used and the experimental conditions. Some workers have found EPS production to be optimal at low temperatures (Cerning et al., 1992; Kojic et al., 1992; Marshall et al., 1995; van den Berg et al., 1995; Gamar et al., 1997), while others have shown EPS production to be favored at much higher temperatures (Grobben et al., 1995; De Vuyst et al., 1998). The optimum $\mathrm{pH}$ for EPS production generally ranges between 5 and 7 . De Vuyst et al. (1998) have shown that optimal EPS production and growth for Streptococcus thermophilus LY03 were at $42^{\circ} \mathrm{C}$ and $\mathrm{pH}$ 6.2. The composition of the medium, nitrogen source (Marshall et al., 1995; De Vuyst et al., 1998; De Vuyst and Degeest, 1999) and carbon source supplementation (Gamar et al., 1997; Degeest et al., 2001) are shown to increase EPS production. Partial replacement of skim milk powder (SMP) with WPC results in a higher buffering capacity compared with that provided by SMP alone due to the contribution of whey proteins, salts such as citrates, phosphates, and lactates (Kailasapathy et al., 1996).

No previous work has speculated on the possibility of culturing a non-EPS producing $S$. thermophilus strain with a second EPS producing strain of $S$. thermophilus. By growing a non-EPS producing Lactobacillus delbrueckii ssp. bulgaricus strain in the presence of an EPS producing $S$. thermophilus strain, it was, however, found that EPS production was stimulated. The level of EPS produced had increased to reach approximately $800 \mathrm{mg} / \mathrm{L}$ (Cerning et al., 1988; Cerning et al., 1990b).

Exopolysaccharide degradation has been linked to the presence of depolymerizing enzymes (Cerning, 1990a; Cerning et al., 1992; De Vuyst et al., 1998; Pham et al., 2000). Many studies have shown the EPS content to decline with prolonged fermentation times (Cerning, 1990a; Cerning et al., 1992; De Vuyst et al., 1998; Pham et al., 2000; Gorret et al., 2001). Pham et al. (2000) studied the possible relationship between cell extract enzymes of Lactobacillus rhamnosus $\mathrm{R}$ and EPS yield and found the presence of various glycohydrolases, including both $\alpha$ - and $\beta$-glucosidase and galactosidase, which were responsible for lowering polymer viscosity and liberating reducing sugars.

Streptococcus thermophilus produces $\beta$-D-galactosidase (Shah and Jelen, 1990), which breaks down the disaccharide lactose to its sugar monomers, glucose, and galactose. Streptococcus thermophilus is homofermentative and produces lactic acid from glucose fermentation. Galactose is collected in the surrounding environment as these bacteria do not metabolize this sugar (Walstra and Jenness, 1984). The objective of this study was to examine the EPS production by $S$. thermophilus 1275 in skim milk medium under varying environmental conditions to understand the relationship between $\mathrm{pH}$, growth temperature, and supplementation with nutrients and non-EPS adjunct cultures in order to improve EPS synthesis and recognize factors that limit their production.

\section{MATERIALS AND METHODS}

\section{Bacterial Strains}

Streptococcus thermophilus 1275 was obtained from the Australian Starter Culture Research Center (ASCRC, Werribee, Australia). This organism produces capsular as well as ropy EPS (Zisu and Shah, unpublished data). The organism was identified as EPS producing by wet-film India ink capsule staining technique (Duguid, 1951) and viscosity measurements. Streptococcus thermophilus 1303, a non-EPS producer was also obtained from ASCRC. Both organisms were stored at $-80^{\circ} \mathrm{C}$ in $10 \%$ (wt/vol) reconstituted skim milk (RSM) containing 20\% (vol/vol) glycerol. Working cultures were propagated three times consecutively using a $1 \%$ (vol/vol) inoculum volume in $10 \%$ $\mathrm{RSM}$ at $37^{\circ} \mathrm{C}$ for $18 \mathrm{~h}$ before use.

\section{Fermentation Experiments and Culture Media}

Skim milk powder was acquired from Murray Goulburn Co-Op. (Brunswick, Melbourne, Australia) and dissolved in distilled water to make RSM (10\%, $\mathrm{wt} / \mathrm{vol}$ ). The RSM was used as the fermentation medium. The RSM medium was sterilized separately at $121^{\circ} \mathrm{C}$ for $15 \mathrm{~min}$ and aseptically transferred into the sterile fermentation vessel. A 2-L Biostat B fermenter (B. Braun Biotech International, Melsungen, Germany) was used for growing S. thermophilus 1275 in $10 \%$ RSM separately at various $\mathrm{pH}(4.5,5.5$, and 6.5$)$ and temperatures $\left(30,37,40\right.$, and $\left.42^{\circ} \mathrm{C}\right)$ for $24 \mathrm{~h}$. Samples were collected at $0 \mathrm{~h}$ and thereafter at 6 -h inter- 
vals for quantification of EPS, cell count, and concentrations of lactose, glucose galactose, and lactic acid. The fermenter together with the corrective solutions [50\% (wt/vol) citric acid (Ajax Chemicals, Sydney, Australia) and $3 \mathrm{M} \mathrm{NaOH}$ ] were sterilized in situ at $121^{\circ} \mathrm{C}$ for $30 \mathrm{~min}$. A $1 \%$ inoculum of $18 \mathrm{~h}$ grown culture was added to $1.8 \mathrm{~L}$ of the medium. The initial $\mathrm{pH}$ of the medium was adjusted with $50 \%$ (wt/vol) citric acid and maintained at the necessary $\mathrm{pH}(4.5,5.5$, and 6.5) with automatic addition of $3 M \mathrm{NaOH}$ required to neutralize lactic acid produced by the microorganisms. The fermenter was operated with agitation (100 $\mathrm{rpm}$ ) to maintain homogeneity of the medium. The required temperatures $\left(30,37,40\right.$, and $\left.42^{\circ} \mathrm{C}\right)$ were maintained automatically.

\section{Sampling}

Three hundred milliliter samples were aseptically withdrawn every $6 \mathrm{~h}$ and immediately cooled on ice before freezing at $-20^{\circ} \mathrm{C}$ to determine the amount of EPS, and concentrations of lactic acid, lactose, glucose, and galactose at a later date. A fresh sample was also taken for immediate enumeration of the bacterial population.

\section{Enumeration of Bacterial Cells}

A 1-ml aliquot of inoculated RSM was sampled and plated every $6 \mathrm{~h}$ using the pour plating technique and M17 agar containing lactose (Amyl Media Co., Dandenong, Melbourne, Australia). Solidified agar plates were incubated aerobically at $37^{\circ} \mathrm{C}$ for $48 \mathrm{~h}$.

\section{Effects of pH on Cell Growth and EPS Production}

Effects of $\mathrm{pH}$ on EPS production were examined separately at $\mathrm{pH} 4.5,5.5$, and 6.5 at $37^{\circ} \mathrm{C}$. The inoculation was carried out as previously mentioned. The desired $\mathrm{pH}$ was maintained automatically over $24 \mathrm{~h}$ using $3 \mathrm{M} \mathrm{NaOH}$ and 50\% (wt/vol) citric acid. Samples were aseptically removed at $0 \mathrm{~h}$ and every $6 \mathrm{~h}$ thereafter. Additionally, the effect of $\mathrm{pH}$ on EPS production was examined by removing $\mathrm{pH}$ automation and allowing the $\mathrm{pH}$ to drop freely during fermentation for $24 \mathrm{~h}$ at $37^{\circ} \mathrm{C}$.

\section{Effects of Temperature on Cell Growth and EPS Production}

Fermentations were conducted separately at 30, 37, 40 , and $42^{\circ} \mathrm{C}$ at $\mathrm{pH}$ 5.5. Optimum $\mathrm{pH}$ was found to be $\mathrm{pH}$ 5.5. Temperature and $\mathrm{pH}$ were maintained automatically as described earlier over $24 \mathrm{~h}$, and samples were aseptically withdrawn at $0 \mathrm{~h}$ and every $6 \mathrm{~h}$ thereafter.

\section{Effects of WPC on Cell Growth and EPS Production}

Whey protein concentrate (WPC) 392 containing $80.4 \%$ protein (New Zealand Dairy Board, Wellington, New Zealand) was used as an additional nitrogen source. The WPC was supplemented to RSM at $0.5 \%$ $(\mathrm{wt} / \mathrm{vol})$ prior to sterilization. Preliminary studies showed that a concentration of $0.5 \%(\mathrm{wt} / \mathrm{vol})$ was adequate for improved growth. Higher concentrations would not be cost effective in food applications. The fermentation was conducted at $\mathrm{pH} 5.5$ and $37^{\circ} \mathrm{C}$, as this $\mathrm{pH}$ and temperature combination was found to be ideal. Furthermore, the effects of $\mathrm{pH}$ and supplementation with WPC 392 on EPS production were also examined by removing the automation and allowing the $\mathrm{pH}$ to drop freely during fermentation for $24 \mathrm{~h}$ at $37^{\circ} \mathrm{C}$.

\section{Effects of Coculturing with Non-EPS S. thermophilus Adjunct Culture on Cell Growth and EPS Production}

The effect of coculturing with non-EPS producing S. thermophilus strain 1303 as an adjunct culture on the EPS production was studied. Two combinations of S. thermophilus 1275 and S. thermophilus 1303 [75:25 (0.75 and 0.25\%) and 50:50 (0.50 and 0.50\%)] were examined based on the initial medium volume. Bacterial cultures were grown separately at the conditions described earlier and an appropriate quantity of each strain was transferred into the fermentation vessel. Fermentations were conducted for $24 \mathrm{~h}$ at $\mathrm{pH}$ 5.5 and $37^{\circ} \mathrm{C}$.

\section{Isolation and Quantification of Exopolysaccharides}

A $100-\mathrm{ml}$ aliquot of the frozen sample was thawed overnight at $4^{\circ} \mathrm{C}$ to which $20 \mathrm{ml}$ of $20 \%$ (wt/vol) trichloroacetic acid solution (Sigma, Melbourne, Australia) was added to precipitate casein followed by centrifugation at $10,000 \times g$ for $20 \mathrm{~min}$ at $4^{\circ} \mathrm{C}$ to remove the precipitate and bacterial cells. The supernatant was neutralized to $\mathrm{pH} 6.8$ with $4 \mathrm{M} \mathrm{NaOH}$ and boiled for $30 \mathrm{~min}$ in a water bath and recentrifuged $(10,000 \times \mathrm{g}$, $20 \mathrm{~min}, 4^{\circ} \mathrm{C}$ ) to remove the remaining precipitated insoluble proteins. An equal volume of chilled ethanol was added to the supernatant to precipitate EPS from solution and agitated at $100 \mathrm{rpm}$ and $4^{\circ} \mathrm{C}$ overnight. The crude EPS pellet was recovered by centrifugation $\left(10,000 \times g, 20 \mathrm{~min}, 4^{\circ} \mathrm{C}\right)$ and resuspended in $10 \mathrm{ml}$ 
of $0.05 M$ Tris-HCl buffer ( $\mathrm{pH} 8.0$ ). Contaminating proteins were digested with $0.2 \mathrm{mg} / \mathrm{ml}$ of proteinase $\mathrm{K}$ (Sigma) overnight at $37^{\circ} \mathrm{C}$. The reaction was stopped by heating at $90^{\circ} \mathrm{C}$ for $10 \mathrm{~min}$, and the EPS was precipitated from the solution with $15 \mathrm{ml}$ of chilled ethanol and followed by centrifugation $(10,000 \times g, 20 \mathrm{~min}$, $4^{\circ} \mathrm{C}$ ). The EPS pellet was suspended in $10 \mathrm{ml}$ of sterile distilled water and sonicated for $120 \mathrm{~min}$ (FX 14PH sonication bath; Unisonics Pty Ltd, Sydney Australia) to soften the pellet and vortexed into a uniform suspension before dialyzing against distilled water for 48 $h$. Two daily changes of distilled water were made. The EPS was quantified using the phenol-sulfuric method (Dubois et al., 1956) as used extensively by others for this purpose (Dubois et al., 1956; Bouzar et al., 1996; Gamar et al., 1997; Gamar-Nourani et al., 1998; Gorret et al., 2001; Grobben et al., 2000; Sebastiani and Zelger, 1998; Torino et al., 2001) and was expressed as a glucose equivalent.

\section{Determination of Lactic Acid, Lactose, Glucose, and Galactose}

High pressure liquid chromatography was used to determine the concentrations of lactic acid, lactose, glucose, and galactose. The HPLC consisted of a Varian 9100 autosampler, equipped with a Varian 9012 solvent delivery system, a Varian Star 9040 refractive index detector, and a SSII 505 LC column oven. Data was collected using Varian software.

Lactic acid. Seventy microliters of concentrated nitric acid and $5930 \mu \mathrm{l}$ of $0.009 \mathrm{~N} \mathrm{H}_{2} \mathrm{SO}_{4}$ were added to $5 \mathrm{ml}$ of homogenous sample for protein digestion, from which a $1.6-\mathrm{ml}$ aliquot was micro-centrifuged (Eppendorf 5415C at maximum speed for $10 \mathrm{~min}$ ) and filtered through a $0.45-\mu \mathrm{l}$ syringe filter. A working volume of $50 \mu \mathrm{l}$ was injected into an Aminex HPX$87 \mathrm{H}$ column (Bio-Rad Laboratories) using $0.009 \mathrm{~N}$ $\mathrm{H}_{2} \mathrm{SO}_{4}$ as the mobile phase, held at $65^{\circ} \mathrm{C}$ using a flow rate of $0.6 \mathrm{ml} / \mathrm{min}$. Lactic acid (Sigma) standard was prepared in $0.009 \mathrm{~N} \mathrm{H}_{2} \mathrm{SO}_{4}$ at appropriate concentrations and run in triplicate at identical conditions.

Lactose, glucose, and galactose. Samples were prepared as with lactic acid, with the exception of replacing sulfuric acid with a mixture of acetonitrile/ water (75:25) as the sample diluent. A working volume of $25 \mu \mathrm{l}$ was injected into an Aminex amino column (Supelco, Australia) using acetonitrile/water (75:25) as the mobile phase, held at $35^{\circ} \mathrm{C}$ using a flow rate of $1.5 \mathrm{ml} / \mathrm{min}$. Lactose was from BDH Laboratory supplies (Pode, England) and glucose and galactose were obtained from Ajax Chemicals (Sydney, Australia). Appropriate concentrations for each sugar were prepared as a standard using the acetonitrile/water
(75:25) mixture and analyzed in triplicate at identical conditions.

\section{Statistical Analysis}

Each fermentation experiment was performed in duplicate. For EPS quantification and bacterial counts, samples were withdrawn in duplicate and each sample was analyzed twice and results are presented as a mean \pm standard error of eight analyses. To find significant differences in EPS production at $24 \mathrm{~h}$, the means for EPS production were analyzed using oneway analysis of variance (ANOVA) with a $95 \%$ confidence interval using Microsoft Excel StatPro. Any ANOVA data with $P<0.05$ was classified as statistically significant. Samples for analysis of concentration of lactic acid, lactose, glucose, and galactose were withdrawn in triplicate and each sample analyzed twice and are presented as means of 12 values. Measurements of $\mathrm{pH}$ during fermentation were taken in duplicate and are presented as means of four determinations.

\section{RESULTS}

\section{Effect of pH of the Growth Medium on Bacterial Growth and EPS Production}

Table 1 shows the influence of $\mathrm{pH}$ on EPS production and bacterial counts as well as the concentrations of lactic acid, lactose, glucose, and galactose during fermentation of RSM with S. thermophilus 1275 . Streptococcus thermophilus 1275 was grown in $10 \%$ (wt/vol) $\mathrm{RSM}$ at $37^{\circ} \mathrm{C}$ over $24 \mathrm{~h}$ at a constant $\mathrm{pH}$ of $4.5,5.5$, or 6.5. There appeared to be a relationship between $\mathrm{pH}$, EPS production and the bacterial growth. There was a significant difference in EPS production between $\mathrm{pH} 4.5,5.5$, and 6.5 after $24 \mathrm{~h}$ of fermentation $(P<0.05)$. The EPS production ceased at $\mathrm{pH} 4.5$, and this $\mathrm{pH}$ created unfavorable growth conditions for the bacterial population. At $\mathrm{pH}$ 5.5, EPS production was favored by $S$. thermophilus 1275 yielding $458 \mathrm{mg} / \mathrm{L}$ in $24 \mathrm{~h}$. The maximum amount of EPS was produced at $24 \mathrm{~h}$, although the death phase followed after $12 \mathrm{~h}$. The growth phase of cells was maintained for a longer period of time before reaching the death phase. Other workers have found $\mathrm{pH} 6.2$ as the optimum $\mathrm{pH}$ for $S$. thermophilus (De Vuyst et al., 1998). On the contrary, $\mathrm{pH} 6.5$ resulted in less EPS production than that at $\mathrm{pH} 5.5$, yielding a maximum of $255 \mathrm{mg} / \mathrm{L}$. At this $\mathrm{pH}$, the cell growth was accelerated over the first $6 \mathrm{~h}$ of the exponential growth phase. The amount of EPS production declined after the first $12 \mathrm{~h}$. The decline in the EPS content observed between $6 \mathrm{~h}(205 \mathrm{mg} / \mathrm{L})$ 
Table 1. Bacterial counts, amount of EPS, ${ }^{1}$ and concentrations of lactic acid, lactose, glucose, and galactose produced during fermentation of $\mathrm{RSM}^{2}$ by Streptococcus thermophilus 1275 at $0,6,12,18$, and $24 \mathrm{~h}$ at various $\mathrm{pH}$ at $37^{\circ} \mathrm{C}$ (mean \pm standard error).

\begin{tabular}{|c|c|c|c|c|c|c|c|}
\hline $\mathrm{pH}$ & $\begin{array}{l}\text { Fermentation } \\
\text { time }(\mathrm{h})\end{array}$ & $\begin{array}{l}\text { EPS } \\
(\mathrm{mg} / \mathrm{L})\end{array}$ & $\begin{array}{l}\text { Bacterial counts } \\
\left(\log _{10} \mathrm{cfu} / \mathrm{ml}\right)\end{array}$ & $\begin{array}{l}\text { Lactic acid } \\
(\mathrm{g} / \mathrm{L})\end{array}$ & $\begin{array}{l}\text { Lactose } \\
(\mathrm{g} / \mathrm{L})\end{array}$ & Glucose & $\begin{array}{l}\text { Galactose } \\
(\mathrm{g} / \mathrm{L})\end{array}$ \\
\hline \multirow[t]{4}{*}{4.5} & 0 & $15 \pm 0.5$ & $5.91 \pm 0.03$ & $\mathrm{ND}^{3}$ & $49.05 \pm 0.60$ & ND & $\mathrm{ND}$ \\
\hline & 6 & $17 \pm 1.4$ & $5.98 \pm 0.04$ & ND & $48.48 \pm 0.60$ & ND & $0.55 \pm 0.02$ \\
\hline & 18 & $16 \pm 0.6$ & $6.04 \pm 0.03$ & $0.64 \pm 0.04$ & $48.37 \pm 0.56$ & ND & $1.19 \pm 0.06$ \\
\hline & 24 & $15 \pm 2.0^{\mathrm{c}}$ & $5.89 \pm 0.05$ & $0.73 \pm 0.05$ & $47.36 \pm 0.38$ & ND & $1.82 \pm 0.06$ \\
\hline \multirow[t]{2}{*}{5.5} & 0 & $13 \pm 1.0$ & $6.00 \pm 0.02$ & ND & $47.70 \pm 1.39$ & ND & ND \\
\hline & 24 & $458 \pm 7.1^{\mathrm{a}}$ & $8.44 \pm 0.00$ & $27.12 \pm 0.22$ & $8.50 \pm 0.08$ & ND & $17.63 \pm 0.26$ \\
\hline \multirow{5}{*}{6.5} & 0 & $15 \pm 0.0$ & $6.09 \pm 0.01$ & ND & $48.46 \pm 0.39$ & ND & ND \\
\hline & 6 & $205 \pm 25.0$ & $8.42 \pm 0.01$ & $2.14 \pm 0.01$ & $9.03 \pm 0.06$ & ND & $16.48 \pm 0.12$ \\
\hline & 12 & $158 \pm 9.5$ & $8.19 \pm 0.02$ & $2.80 \pm 0.01$ & $0.07 \pm 0.02$ & ND & $19.06 \pm 0.26$ \\
\hline & 18 & $227 \pm 15.0$ & $8.11 \pm 0.03$ & $3.02 \pm 0.02$ & $0.00 \pm 0.00$ & ND & $20.37 \pm 0.09$ \\
\hline & 24 & $255 \pm 5.3^{\mathrm{b}}$ & $8.00 \pm 0.05$ & $2.84 \pm 0.01$ & $0.00 \pm 0.00$ & ND & $20.68 \pm 0.21$ \\
\hline
\end{tabular}

${ }^{\mathrm{a}, \mathrm{b}, \mathrm{c}}$ One-way ANOVA of EPS $(\mathrm{mg} / \mathrm{L})$ means at $24 \mathrm{~h}$ between $\mathrm{pH}$ variables. Means in the same column with different superscript are significantly different $(P<0.05)$.

${ }^{1} \mathrm{EPS}=$ Exopolysaccharides.

${ }^{2} \mathrm{RSM}=$ Reconstituted skim milk.

${ }^{3} \mathrm{ND}=$ Not detected.

and $12 \mathrm{~h}(158 \mathrm{mg} / \mathrm{L})$ of fermentation may be due to enzymic degradation.

Hence, the $\mathrm{pH}$ of 5.5 was chosen for the rest of the experiments for examining other variables such as temperature.

The lactose content in the RSM was $4.9 \%$. At pH 4.5 , a small amount of lactose (3.4\%) was utilized and consequently a low level of galactose accumulated. At $\mathrm{pH} 5.5,82 \%$ of the lactose was utilized, whereas at $\mathrm{pH} 6.5$, all the lactose was utilized after $18 \mathrm{~h}$ of fermentation. Highest level of lactic acid was produced at $\mathrm{pH}$ 5.5. At $\mathrm{pH}$ 6.5, there was an increase in lactose catabolism during the initial stages of the fermentation, and the glucose moiety was possibly used in EPS production, consequently resulting in a small amount of lactic acid production with a continued accumulation of the galactose moiety. The EPS biosynthesis from the catabolism of lactose by $S$. thermophilus via a lactose and galactose antitransport system was described by De Vuyst et al. (1999). No glucose was detected in samples in our study, suggesting that this sugar was metabolized completely.

When the $\mathrm{pH}$ was allowed to drop freely due to acid production by the fermenting organism (Table 2), EPS production continued over the $24 \mathrm{~h}$, reaching a maximum of $406 \mathrm{mg} / \mathrm{L}$. Cell numbers were higher than those observed when the $\mathrm{pH}$ was maintained at $\mathrm{pH}$ 5.5. It is interesting to note that higher amount of EPS was produced and more lactose was utilized at $\mathrm{pH} 4.08$ when the $\mathrm{pH}$ was allowed to drop freely than at a constant $\mathrm{pH} 4.5$. At $\mathrm{pH} 4.5$, S. thermophilus 1275 did not grow out of the lag phase, whereas with a free drop in $\mathrm{pH}$ starting from $\mathrm{pH}$ 6.37, the $S$. thermophilus 1275 population was able to increase before reaching unfavorable $\mathrm{pH}$ levels.

\section{Effect of Temperature on Growth and EPS Production}

Table 3 shows the effects of temperature on the growth of $S$. thermophilus 1275 and EPS production. Streptococcus thermophilus 1275 was grown in RSM at $30,37,40$, and $42^{\circ} \mathrm{C}$, while the $\mathrm{pH}$ was kept constant at 5.5. As shown in the table, the optimum temperature for EPS production was $40^{\circ} \mathrm{C}$, yielding $622 \mathrm{mg} / \mathrm{L}$ of EPS at $24 \mathrm{~h}$ of fermentation. De Vuyst et al. (1998) found $42^{\circ} \mathrm{C}$ as the optimum temperature for the growth and EPS production by $S$. thermophilus. However, mesophilic microorganisms showed greater EPS production at much lower temperatures (Cerning et al., 1992; Gamar et al., 1997; Kojic et al., 1992; van den Berg et al., 1995).

At $24 \mathrm{~h}$, EPS production was significantly less at 30 and $42^{\circ} \mathrm{C}$ than the amount of EPS quantified at $40^{\circ} \mathrm{C}$ $(P<0.05)$. At $30^{\circ} \mathrm{C}$, EPS production was slow at $6 \mathrm{~h}$ and a maximum of $390 \mathrm{mg} / \mathrm{L}$ was produced at $24 \mathrm{~h}$. Cell counts were also much lower at this temperature. Thus a temperature of $30^{\circ} \mathrm{C}$ appeared to be suboptimal for both cell growth and EPS production. The EPS production was also lower at $42^{\circ} \mathrm{C}$ yielding a maximum of only $322 \mathrm{mg} / \mathrm{L}$. The amount of lactose utilized was highest $(86 \%)$ at $42^{\circ} \mathrm{C}$ compared with $82 \%$ at $37^{\circ} \mathrm{C}$ and $63 \%$ at $40^{\circ} \mathrm{C}$. Galactose accumulated over time. It is interesting to note that the highest amount of 
Table 2. Bacterial counts, amount of EPS, ${ }^{1}$ and concentrations of lactic acid, lactose, glucose, and galactose produced during fermentation of $\mathrm{RSM}^{2}$ at $0,6,12,18$, and $24 \mathrm{~h}$ by Streptococcus thermophilus 1275 at $37^{\circ} \mathrm{C}$ (mean \pm standard error).

\begin{tabular}{lllllllll}
\hline & $\begin{array}{l}\text { Fermentation } \\
\text { time }(\mathrm{h})\end{array}$ & $\mathrm{pH}$ & $\begin{array}{l}\mathrm{EPS} \\
(\mathrm{mg} / \mathrm{L})\end{array}$ & $\begin{array}{l}\text { Bacterial counts } \\
\left(\log _{10} \mathrm{cfu} / \mathrm{ml}\right)\end{array}$ & $\begin{array}{l}\text { Lactic acid } \\
(\mathrm{g} / \mathrm{L})\end{array}$ & $\begin{array}{l}\text { Lactose } \\
(\mathrm{g} / \mathrm{L})\end{array}$ & $\begin{array}{l}\text { Galactose } \\
(\mathrm{g} / \mathrm{L})\end{array}$ \\
\hline $\mathrm{RSM}$ & 0 & $6.37 \pm 0.01$ & $12 \pm 1.5^{\mathrm{d}}$ & $6.02 \pm 0.04$ & $\mathrm{ND}^{3}$ & $51.50 \pm 0.40$ & $\mathrm{ND}$ & $\mathrm{ND}$ \\
& 6 & $4.97 \pm 0.04$ & $171 \pm 16.0^{\mathrm{c}}$ & $8.01 \pm 0.02$ & $1.55 \pm 0.01$ & $42.05 \pm 0.46$ & $\mathrm{ND}$ & $6.36 \pm 0.11$ \\
& 12 & $4.37 \pm 0.04$ & $201 \pm 200^{\mathrm{b}}$ & $7.99 \pm 0.02$ & $2.33 \pm 0.00$ & $41.07 \pm 0.69$ & $\mathrm{ND}$ & $8.30 \pm 0.14$ \\
& $4.17 \pm 0.01$ & $342 \pm 29.5^{\mathrm{a}}$ & $7.97 \pm 0.01$ & $2.82 \pm 0.01$ & $38.96 \pm 0.57$ & $\mathrm{ND}$ & $9.51 \pm 0.30$ \\
& 24 & $4.08 \pm 0.005$ & $406 \pm 13.3^{\mathrm{a}}$ & $8.06 \pm 0.03$ & $3.09 \pm 0.02$ & $35.35 \pm 0.42$ & $\mathrm{ND}$ & $9.61 \pm 0.09$ \\
\hline
\end{tabular}

${ }^{1} \mathrm{EPS}=$ Exopolysaccharides.

${ }^{2} \mathrm{RSM}=$ Reconstituted skim milk.

${ }^{3} \mathrm{ND}=$ Not detected

lactose was metabolized at $42^{\circ} \mathrm{C}$; however, the maximum amount of EPS was produced at $40^{\circ} \mathrm{C}$.

\section{Influence of Supplementation with WPC on Cell Growth and EPS Production}

Table 4 shows the growth of $S$. thermophilus 1275 and EPS production as affected by the addition of WPC $392(0.5 \%$, wt/vol $)$ at $\mathrm{pH} 5.5$ and $37^{\circ} \mathrm{C}$. The EPS production increased uniformly over the $24 \mathrm{~h}$ of fermentation at a greater rate when supplemented with WPC compared with that with RSM. After $24 \mathrm{~h}$ of fermentation, the amount of EPS produced significantly increased $(P<0.05)$ from $458 \mathrm{mg} / \mathrm{L}$ (without WPC) to a remarkable amount of $1029 \mathrm{mg} / \mathrm{L}$ with WPC supple- mentation. Cell counts were lower with WPC supplementation than those with RSM, suggesting that the nutrients from WPC were used in the synthesis of EPS rather that for cell growth. A similar level of lactose consumption and galactose accumulation was evident between the two variables; however, lactic acid production was lower when RSM was supplemented with WPC. The addition of WPC when fermenting at $\mathrm{pH}$ 5.5 and $37^{\circ} \mathrm{C}$ (Table 2) resulted in producing $12.33 \mathrm{~g} /$ L of lactic acid by $S$. thermophilus 1275 , the amount significantly less than that resulted from fermentation of RSM in which $27.12 \mathrm{~g} / \mathrm{L}$ of lactic acid was produced at $24 \mathrm{~h}$. The rate of lactose hydrolysis and the formation of galactose were similar in both instances.

Table 3. Bacterial counts, amount of EPS,${ }^{1}$ and concentrations of lactic acid, lactose, glucose, and galactose produced during fermentation of $\mathrm{RSM}^{2}$ by Streptococcus thermophilus 1275 at $0,6,12,18$, and $24 \mathrm{~h}$ at $\mathrm{pH} 5.5$ and various temperatures (mean \pm standard error).

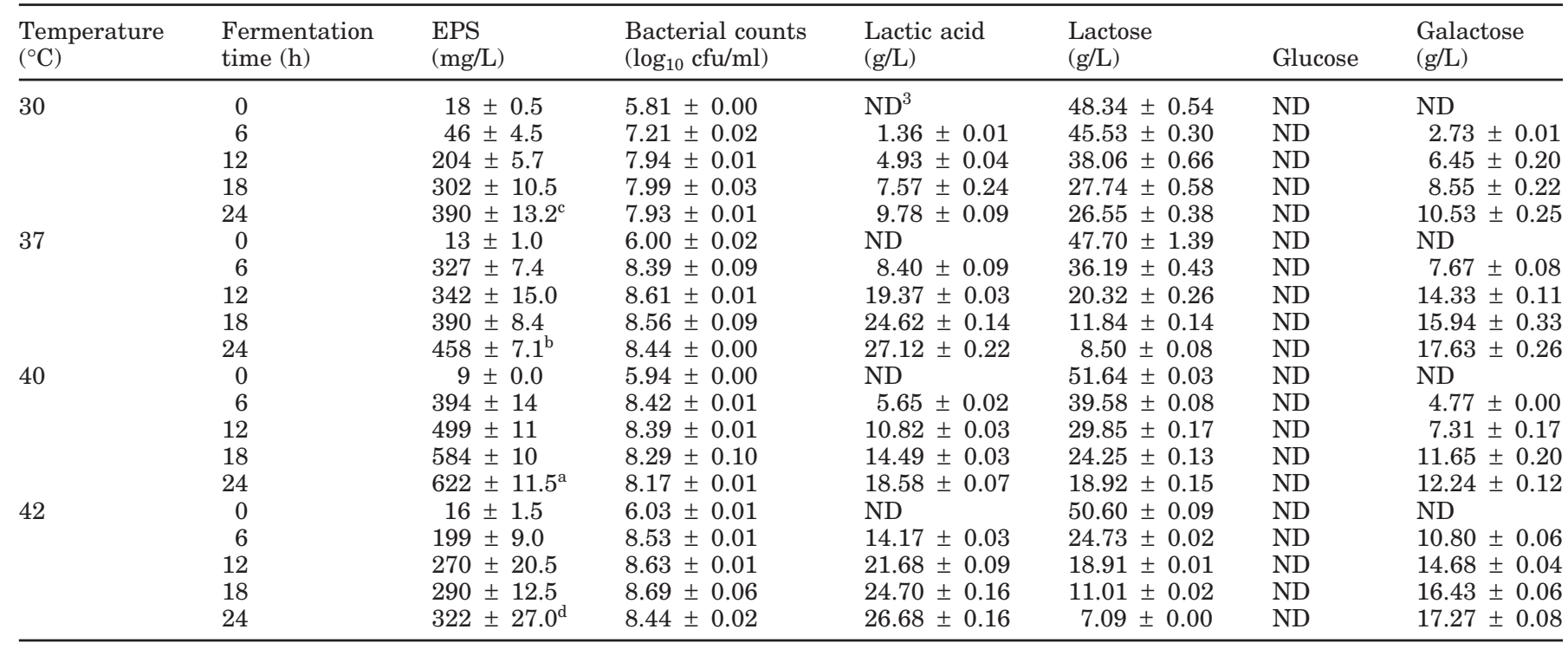

a,b,c,d One-way ANOVA of EPS (mg/L) means at $24 \mathrm{~h}$ between temperature variables. Means in the same column with different superscript are significantly different $(P<0.05)$.

${ }^{1} \mathrm{EPS}=$ Exopolysaccharides.

${ }^{2} \mathrm{RSM}=$ Reconstituted skim milk.

${ }^{3} \mathrm{ND}=$ Not detected. 
Table 4. Bacterial counts, amount of EPS, ${ }^{1}$ and concentrations of lactic acid, lactose, glucose, and galactose produced by Streptococcus thermophilus 1275 in $\mathrm{RSM}^{2}$ supplemented with $\mathrm{WPC}^{3} 392$ at $0,6,12,18$, and $24 \mathrm{~h}$ at $\mathrm{pH} 5.5$ and $37^{\circ} \mathrm{C}$ (mean \pm standard error).

\begin{tabular}{|c|c|c|c|c|c|c|c|}
\hline Growth media & $\begin{array}{l}\text { Fermentation } \\
\text { time }(\mathrm{h})\end{array}$ & $\begin{array}{l}\text { EPS } \\
(\mathrm{mg} / \mathrm{L})\end{array}$ & $\begin{array}{l}\text { Bacterial counts } \\
\left(\log _{10} \mathrm{cfu} / \mathrm{ml}\right)\end{array}$ & $\begin{array}{l}\text { Lactic acid } \\
(\mathrm{g} / \mathrm{L})\end{array}$ & $\begin{array}{l}\text { Lactose } \\
(\mathrm{g} / \mathrm{L})\end{array}$ & Glucose & $\begin{array}{l}\text { Galactose } \\
(\mathrm{g} / \mathrm{L})\end{array}$ \\
\hline \multirow[t]{4}{*}{$\mathrm{RSM}$} & 0 & $13 \pm 1.0$ & $6.00 \pm 0.02$ & $\mathrm{ND}^{4}$ & $47.70 \pm 1.39$ & ND & $\mathrm{ND}$ \\
\hline & 6 & $327 \pm 7.4$ & $8.39 \pm 0.09$ & $8.40 \pm 0.09$ & $36.19 \pm 0.43$ & ND & $7.67 \pm 0.08$ \\
\hline & 18 & $390 \pm 8.4$ & $8.56 \pm 0.09$ & $24.62 \pm 0.14$ & $11.84 \pm 0.14$ & ND & $15.94 \pm 0.33$ \\
\hline & 24 & $458 \pm 7.1^{\mathrm{b}}$ & $8.44 \pm 0.00$ & $27.12 \pm 0.22$ & $8.50 \pm 0.08$ & ND & $17.63 \pm 0.26$ \\
\hline \multirow{2}{*}{ RSM + 0.5\% WPC 392} & 0 & $15 \pm 2.0$ & $5.79 \pm 0.05$ & ND & $49.10 \pm 0.43$ & ND & ND \\
\hline & 24 & $1029 \pm 14.1^{\mathrm{a}}$ & $8.12 \pm 0.05$ & $12.33 \pm 0.05$ & $8.24 \pm 0.39$ & ND & $18.63 \pm 0.09$ \\
\hline
\end{tabular}

${ }^{\mathrm{a}, \mathrm{b}}$ One-way ANOVA of EPS (mg/L) means at $24 \mathrm{~h}$ between variables. Means in the same column with different superscript are significantly different $(P<0.05)$.

${ }^{1} \mathrm{EPS}=$ Exopolysaccharides

${ }^{2} \mathrm{RSM}=$ Reconstituted skim milk.

${ }^{3} \mathrm{WPC}=$ Whey protein concentrate

${ }^{4} \mathrm{ND}=$ Not detected.

There was a rapid increase in the amount of EPS with uncontrolled $\mathrm{pH}$ in the first $12 \mathrm{~h}$ of fermentation, then the EPS production slowed as the $\mathrm{pH}$ dropped, reflecting the impact of acid on EPS production (Table 5). After $24 \mathrm{~h}$, EPS production was less than half compared with that produced at an optimal $\mathrm{pH}$ of 5.5. There was little difference in the amount of EPS produced after $24 \mathrm{~h}$ of fermentation upon supplementation with WPC $(491 \mathrm{mg} / \mathrm{L})$ or without WPC $(406 \mathrm{mg} /$ $\mathrm{L})$. The final $\mathrm{pH}$ reached was higher $(\mathrm{pH} 4.21)$ and $2.24 \mathrm{~g} / \mathrm{L}$ of lactic acid was produced with WPC addition compared with $\mathrm{pH}$ of 4.08 and $3.09 \mathrm{~g} / \mathrm{L}$ of lactic acid with RSM (Table 2). This was possibly due to the buffering effects of WPC. Kailasapathy et al. (1996) have shown that protein and phosphates from the addition of WPC improved buffering capacity. There was less lactose hydrolyzed in batches with uncontrolled $\mathrm{pH}$, even with supplementation with WPC (Table 5), suggesting the role of acid in EPS production.

\section{Effect of Non-EPS S. thermophilus Adjunct Culture on Growth and EPS Production}

Effects of fermentation with a combination of EPS and non-EPS producing $S$. thermophilus on production of EPS is shown in Table 6. Two combinations were examined, a 50\% mixture of each strain, and a mixture consisting of $75 \%$ of S. thermophilus 1275 and $25 \%$ of S. thermophilus 1303 . Fermentations were performed at $\mathrm{pH} 5.5$ and $37^{\circ} \mathrm{C}$. The presence of adjunct $S$. thermophilus 1303 showed a significant increase $(P<0.05)$ in EPS production after $24 \mathrm{~h}$. Cell counts were lower in batches containing mixtures of EPS producing $S$. thermophilus and non-EPS S. thermophilus; however, the enumeration technique used was unable to ascertain the proportion of EPS and non-EPS strains. The $50 \%$ mixture of each strain showed the slowest response in EPS production after $6 \mathrm{~h}$ due to the reduced numbers of the EPS producing bacteria; however, after $12 \mathrm{~h}$ the cell numbers reached high

Table 5. Bacterial counts, amount of EPS, ${ }^{1}$ and concentrations of lactic acid, lactose, glucose, and galactose produced by Streptococcus thermophilus 1275 during fermentation of $\mathrm{RSM}^{1}$ supplemented with WPC 392 at $0,6,12$, 18, and $24 \mathrm{~h}$ at $37^{\circ} \mathrm{C}$ (mean \pm standard error).

\begin{tabular}{|c|c|c|c|c|c|c|c|c|}
\hline & $\begin{array}{l}\text { Fermentation } \\
\text { time }(\mathrm{h})\end{array}$ & $\mathrm{pH}$ & EPS & $\begin{array}{l}\text { Bacterial counts } \\
\left(\log _{10} \mathrm{cfu} / \mathrm{ml}\right)\end{array}$ & $\begin{array}{l}\text { Lactic acid } \\
(\mathrm{g} / \mathrm{L})\end{array}$ & $\begin{array}{l}\text { Lactose } \\
(\mathrm{g} / \mathrm{L})\end{array}$ & Glucose & $\begin{array}{l}\text { Galactose } \\
(\mathrm{g} / \mathrm{L})\end{array}$ \\
\hline \multirow[t]{4}{*}{$\mathrm{RSM}+0.5 \% \mathrm{WPC}$} & 0 & $6.39 \pm 0.02$ & $12 \pm 0$ & $6.07 \pm 0.03$ & $\mathrm{ND}^{3}$ & $48.96 \pm 0.84$ & ND & ND \\
\hline & 6 & $4.94 \pm 0.02$ & $292 \pm 0$ & $8.17 \pm 0.00$ & $1.02 \pm 0.02$ & $39.14 \pm 0.01$ & ND & $5.91 \pm 0.09$ \\
\hline & 18 & $4.34 \pm 0.005$ & $455 \pm 8.3$ & $8.05 \pm 0.01$ & $2.08 \pm 0.03$ & $32.69 \pm 0.33$ & ND & $8.73 \pm 0.31$ \\
\hline & 24 & $4.21 \pm 0.015$ & $491 \pm 10.3$ & $8.05 \pm 0.02$ & $2.24 \pm 0.03$ & $31.03 \pm 0.93$ & ND & $11.05 \pm 0.15$ \\
\hline
\end{tabular}

${ }^{1} \mathrm{EPS}=$ Exopolysaccharides.

${ }^{2} \mathrm{RSM}=$ Reconstituted skim milk.

${ }^{3} \mathrm{ND}=$ Not detected. 
Table 6. Bacterial counts, amount of EPS, ${ }^{1}$ and concentrations of lactic acid, lactose, glucose, and galactose produced by Streptococcus thermophilus 1275 and $S$. thermophilus 1303 in $\mathrm{RSM}^{2}$ at $0,6,12,18$, and $24 \mathrm{~h}$ of fermentation at $\mathrm{pH} 5.5$ and $37^{\circ} \mathrm{C}$ (mean \pm standard error).

\begin{tabular}{|c|c|c|c|c|c|c|c|}
\hline Strain ratio & $\begin{array}{l}\text { Fermentation } \\
\text { time }(\mathrm{h})\end{array}$ & $\begin{array}{l}\mathrm{EPS} \\
(\mathrm{mg} / \mathrm{L})\end{array}$ & $\begin{array}{l}\text { Bacterial counts } \\
\left(\log _{10} \mathrm{cfu} / \mathrm{ml}\right)\end{array}$ & $\begin{array}{l}\text { Lactic acid } \\
(\mathrm{g} / \mathrm{L})\end{array}$ & $\begin{array}{l}\text { Lactose } \\
(\mathrm{g} / \mathrm{L})\end{array}$ & Glucose & $\begin{array}{l}\text { Galactose } \\
(\mathrm{g} / \mathrm{L})\end{array}$ \\
\hline \multirow[t]{4}{*}{ 100\% S. thermophilus 1275} & 0 & $13 \pm 1.0$ & $6.00 \pm 0.02$ & $\mathrm{ND}^{3}$ & $47.70 \pm 1.39$ & ND & ND \\
\hline & 6 & $327 \pm 7.4$ & $8.39 \pm 0.09$ & $8.40 \pm 0.09$ & $36.19 \pm 0.43$ & ND & $7.67 \pm 0.08$ \\
\hline & 18 & $390 \pm 8.4$ & $8.56 \pm 0.09$ & $24.62 \pm 0.14$ & $11.84 \pm 0.14$ & ND & $15.94 \pm 0.33$ \\
\hline & 24 & $458 \pm 7.1^{\mathrm{c}}$ & $8.44 \pm 0.00$ & $27.12 \pm 0.22$ & $8.50 \pm 0.08$ & ND & $17.63 \pm 0.26$ \\
\hline $50 \%$ S. thermophilus 1275 & 0 & $12 \pm 2.5$ & $5.37 \pm 0.01$ & ND & $48.82 \pm 0.22$ & ND & ND \\
\hline & 18 & $613 \pm 6.4$ & $7.98 \pm 0.02$ & $11.38 \pm 0.09$ & $4.90 \pm 0.08$ & ND & $17.99 \pm 0.13$ \\
\hline & 24 & $676 \pm 17.1^{\mathrm{b}}$ & $7.75 \pm 0.01$ & $12.41 \pm 0.08$ & $2.66 \pm 0.14$ & ND & $18.00 \pm 0.08$ \\
\hline $75 \%$ S. thermophilus 1275 & 0 & $15 \pm 1.5$ & $5.53 \pm 0.03$ & ND & $49.79 \pm 0.36$ & ND & ND \\
\hline $25 \%$ non-EPS & 6 & $391 \pm 31.5$ & $8.10 \pm 0.01$ & $10.68 \pm 0.37$ & $32.70 \pm 0.12$ & ND & $9.07 \pm 0.18$ \\
\hline \multirow[t]{3}{*}{ S. thermophilus 1303} & 12 & $645 \pm 13.0$ & $8.13 \pm 0.02$ & $23.22 \pm 0.35$ & $13.33 \pm 0.33$ & ND & $15.66 \pm 0.20$ \\
\hline & 18 & $720 \pm 3.7$ & $7.99 \pm 0.04$ & $29.04 \pm 0.14$ & $6.79 \pm 0.28$ & ND & $17.98 \pm 0.13$ \\
\hline & 24 & $832 \pm 12.8^{\mathrm{a}}$ & $7.97 \pm 0.01$ & $31.41 \pm 0.07$ & $3.66 \pm 0.09$ & ND & $18.21 \pm 0.11$ \\
\hline
\end{tabular}

a,b,c One-way ANOVA of EPS (mg/L) means at $24 \mathrm{~h}$ between culture inoculation variables. Means in the same column with different superscript are significantly different $(P<0.05)$.

${ }^{1} \mathrm{EPS}=$ Exopolysaccharides.

${ }^{2} \mathrm{RSM}=$ Reconstituted skim milk.

${ }^{3} \mathrm{ND}=$ Not detected

levels producing $676 \mathrm{mg} / \mathrm{L}$ of EPS after $24 \mathrm{~h}$. A $75 \%$ EPS strain and $25 \%$ non-EPS S. thermophilus mixture showed the highest quantity of EPS production of 832 $\mathrm{mg} / \mathrm{L}$ at $24 \mathrm{~h}$. Unlike the $50 \%$ combination, the $75 \%$ EPS mixture showed rapid EPS production in the initial stages of the fermentation. Reducing the numbers of EPS bacteria had adverse effects on EPS production in the initial stages as well as on the ultimate amount of EPS produced. Overall, it appears that adjunct nonEPS starter cultures have the potential to increase production of EPS and may be utilized as a cheap alternative to nutrient supplementation.

\section{DISCUSSION}

Excretion of microbially derived exopolysaccharides varies greatly between different strains of LAB and also within species. Cerning et al. (1990) reported EPS production of $337 \mathrm{mg} / \mathrm{L}$ by a strain of $S$. thermophilus, while De Vust et al. (1998) showed EPS production of $546 \mathrm{mg} / \mathrm{L}$ by another strain of $S$. thermophilus. In our study, S. thermophilus 1275 was found to produce 406 $\mathrm{mg} / \mathrm{L}$ of EPS without $\mathrm{pH}$ control and $458 \mathrm{mg} / \mathrm{L}$ when an optimum $\mathrm{pH} 5.5$ was maintained at $37^{\circ} \mathrm{C}$.

Both the ropy and capsular constituents of EPS produced by $S$. thermophilus 1275 were quantified as a whole and reported as the total concentration of EPS. Capsular EPS was removed from the cell surface after precipitation of proteins with TCA and collected in the supernatant along with the ropy EPS using highspeed centrifugation. Although both types of EPS were produced by the strain being investigated, it was the ropy form that had greatest impact on the amount of EPS produced as it was directly secreted into the medium where it accumulated. Our previous work with both capsular and ropy strains of $S$. thermophilus yielded largest amounts of ropy EPS that coincided with altered physical properties of the medium, while only moderate EPS increases were detected with capsular strains without obvious changes in physical properties of the medium (unpublished data). Because the capsular component remains attached to the cell surface, this form of EPS is likely to alter slightly with time and is proportionate to the number of bacterial cells present. It is therefore expected that any increase of capsular EPS would occur in the early stages of fermentation as the number of bacteria increase in the exponential growth phase.

The composition of the medium is vital to the production of EPS; it affects the amount of EPS produced from individual strains. In a separate study, M17 medium used to specifically culture $S$. thermophilus, although supported cell growth, failed to sustain EPS production (Zisu and Shah, unpublished data). Similar findings have been reported by De Vuyst et al. (1998). A favorable carbon/nitrogen ratio complemented by vitamins and minerals such as that found in milk media, when further supplemented with WPC resulted in an enhanced EPS production, reaching $1029 \mathrm{mg} / \mathrm{L}$ after $24 \mathrm{~h}$ when a desired $\mathrm{pH} 5.5$ was maintained, representing one of the highest yields ever achieved by a $S$. thermophilus strain. It was also shown that without $\mathrm{pH}$ control, the yield of EPS was much lower, hence high yields of EPS under practical 
applications such as that used in the fermentation of food may not be achieved.

Exopolysaccharide production is influenced by $\mathrm{pH}$; however, the optimum $\mathrm{pH}$ may vary. Most researchers have shown the optimum $\mathrm{pH}$ for EPS synthesis to be around $\mathrm{pH} 6$. In our study, a lower $\mathrm{pH}$ of 5.5 resulted in an increase in EPS production by increasing the time the culture remains in the exponential growth phase as well as in the stationary phase.

Exopolysaccharide production was shown to be mainly growth associated, hence the greatest rate of EPS production occurred under conditions optimal for growth (temperature and $\mathrm{pH}$ ). The EPS biosynthesis began simultaneously with cell growth and was greatest over the first 6 to $12 \mathrm{~h}$ of fermentation during the exponential growth phase. This trend indicated primary metabolite kinetics; however, there was no significant statistical difference in EPS production between $18 \mathrm{~h}$ and $24 \mathrm{~h}$ of fermentation within any variable (statistics not shown). Many workers have published similar findings (Manca de Nadra et al., 1985; Kojic et al., 1992). As the cell population entered the stationary phase the production of EPS slowed, however, there was an increase in EPS production over the entire $24 \mathrm{~h}$, even when the cells had reached the death phase. This trend in EPS production was evident when conditions were favorable such as fermentation at $\mathrm{pH} 5.5$ and $40^{\circ} \mathrm{C}$, and with the addition of WPC while pH 5.5 was maintained. Similar fermentation patterns were demonstrated by De Vuyst et al. (1998) with $S$. thermophilus LY03. It was suggested that slowing of EPS production over time occurred due to a possible enzymic degradation of EPS in the medium (De Vuyst et al., 1998; Degeest et al., 2001).

It has been shown that enhanced EPS production is achieved for other strains including $S$. thermophilus when increasing the nitrogen availability in the medium, generally by means of yeast extract and/or peptone addition (De Vuyst et al., 1998; Gorret et al., 2001). In our experiment, supplementation with WPC 392 , provided an additional nitrogen source by providing peptides and amino acids made readily available for cell metabolism throughout the 24-h experiment and showed a gradual increase in EPS production. It was shown that the availability of a nitrogen source was more important for increasing the total yield of EPS produced as $S$. thermophilus has the capability of catabolizing larger proteins. The simpler peptides and amino acid constituents of WPC that are responsible for increased EPS synthesis and are indirectly responsible to sustain catabolism of lactose to glucose and galactose and EPS biosynthesis as depicted by De Vuyst and Degeest (1999). Glucose resulting from lactose hydrolysis is used in the structuring of the backbone of the EPS molecules. After $24 \mathrm{~h}$, there was a $55 \%$ increase in EPS production when supplementing with WPC. On the contrary, in pure RSM with the gradual depletion of these vital nutrients, the rate of EPS synthesis slowed after $6 \mathrm{~h}$ of fermenting.

Limited information can be found in literature relating to how EPS production is influenced by the presence of adjunct, non-EPS producing LAB. The EPS produced by $S$. thermophilus increases when grown in the presence of $L$. delbrueckii ssp. bulgaricus (Cerning et al., 1988; Cerning et al., 1990b). Lactobacillus delbrueckii spp. bulgaricus has an optimum working $\mathrm{pH}$ range lower than that for S. thermophilus when used to ferment foods. In our study, we used a bacterial species that was most metabolically active at a similar $\mathrm{pH}$ range as the EPS producer. The objective was to find if supplementation with non-EPS $S$. thermophilus could further stimulate the synthesis of EPS by functioning optimally in the same $\mathrm{pH}$ range, thus depicting the early stages of bacterial fermentation in foods such as the production of yogurt before the $\mathrm{pH}$ drops to levels favoring other bacterial species such as the lactobacilli. When S. thermophilus 1275 was grown in the presence of a non-EPS producing $S$. thermophilus 1303 adjunct culture, the amount of EPS increased to $832 \mathrm{mg} / \mathrm{L}$ at $24 \mathrm{~h}$. The increase in the synthesis of EPS due to the addition of $S$. thermophilus 1303 may be an indication of a complementary relationship that existed between the two strains of $S$. thermophilus. Both coculturing combinations showed a sustained increase in EPS production over $24 \mathrm{~h}$ of fermentation to closely resemble the pattern observed while supplementing with WPC, unlike that of the pure strain, where the rate of EPS synthesis slowed after $6 \mathrm{~h}$ as a result of essential nutrient depletion. This suggests that there was a gradual release of peptides and amino acids that were readily available to the bacterial cells, similar to that observed with the symbiotic relationship that exists between $S$. thermophilus and L. delbrueckii spp. bulgaricus in yogurt preparation that has been found to improve the growth of the bacterial population (Adams and Moss, 1997). Furthermore, the same circumstances were also shown to increase growth of probiotic bacteria (Dave and Shah, 1998). In our experiments, S. thermophilus 1303 not only provided essential nutrients to sustain cell metabolism, but also sustained EPS synthesis. However, the beneficial effects of coculturing on EPS production can only be achieved to such a magnitude if the strain is a ropy EPS producer. As previously described, the amount of capsular EPS synthesized is related to the number of bacterial cells present as the capsules remain cell bound. The EPS concentrations will therefore be lower when coculturing with capsule-produc- 
ing strains, if these bacterial cells lack the ability to release ropy EPS due to the lower initial inoculum concentrations. After $24 \mathrm{~h}$ of fermentation of $S$. thermophilus 1275 in conjunction with $S$. thermophilus 1303 , there was a $45 \%$ increase in the EPS production with the $75 \%$ EPS coculture combination and a $32 \%$ increase with the 50\% EPS coculture combination.

The fermentation pattern of $S$. thermophilus 1275 is homofermentative. The gradual decrease in the concentration of lactose in the fermentation medium as observed in Tables 1 to 6 was due to the activity of $\beta$ D-galactosidase produced by the fermenting bacteria, where lactose is hydrolyzed to glucose and galactose. Glucose not used in EPS biosynthesis was completely converted to lactic acid by glycolytic degradation and galactose was accumulated into the medium. Streptococcus thermophilus lacks the ability to metabolize galactose (De Vuyst and Degeest, 1999). Lactose was completely degraded at $\mathrm{pH} 6.5$, which corresponded to high lactic acid production and rapid growth. At $\mathrm{pH} 4.5$ (Table 1), there was little metabolic activity and comparatively a small amount of lactose was converted to lactic acid.

\section{CONCLUSIONS}

The EPS production by $S$. thermophilus 1275 was shown to be growth associated. The optimum temperature for the production of EPS by $S$. thermophilus 1275 was $40^{\circ} \mathrm{C}$ and $\mathrm{pH}$ 5.5. Fermentation under these conditions yielded $458 \mathrm{mg} / \mathrm{L}$ of EPS. Exopolysaccharide production, cell growth, metabolism of lactose, and lactic acid production by $S$. thermophilus 1275 were influenced by the $\mathrm{pH}$ of the medium, temperature of incubation, supplementation with WPC and non-EPS producing adjunct $S$. thermophilus culture. Addition of WPC and adjunct starter cultures showed improved production of EPS. Supplementation with WPC at optimum temperature and $\mathrm{pH}$ yielded $1029 \mathrm{mg} / \mathrm{L}$ of EPS, whereas coculturing with non-EPS $S$. thermophilus at optimum temperature and $\mathrm{pH}$ yielded $832 \mathrm{mg} / \mathrm{L}$ of EPS. The use of non-EPS producing adjunct $S$. thermophilus could be used as a cheaper alternative to supplementation with WPC as a means of increasing the production of EPS.

\section{ACKNOWLEDGMENTS}

We thank ARC, Strategic Partnership with industry for Research and Training Scheme for funding this project. We also thank Gary Harvey from Dairy Farmers, Tingalpa, Queensland, Australia, for the ongoing support of this research.

\section{REFERENCES}

Adams, M. R., and M. O. Moss. 1997. Food Microbiology. The Royal Society of Chemistry, Guildford, UK.

Ariga, H., T. Urashima, E. Michihata, M. Ito, N. Morizono, T. Kimura, and S. Takahashi. 1992. Extracellular polysaccharide from encapsulated Streptococcus salivarius subsp. thermophilus OR 901 isolated from commercial yoghurt. J. Food Sci. 57:625-628.

Bouzar, F., J. Cerning, and M. Desmazeaud. 1996. Exopolysaccharide production in milk by Lactobacillus delbrueckii ssp. bulgaricus CNRZ 1187 and by two colonial variants. J. Dairy Sci. 79:205-211.

Broadbent, J. R., D. J. Mc Mahon, D. L. Welker, C. J. Oberg, and S. Moineau. 2003. Biochemistry, Genetics, and Applications of Exopolysaccharide production Streptococcus thermophilus: a review. J. Dairy Sci. 86:407-423.

Castern, W. H. M. v., C. Dijkema, H. A. Schols, G. Beldman, and A. G. J. Voragen. 1998. Characterisation and modification of the exopolysaccharide produced by Lactococcus lactis subsp. cremoris B40. Carbohydr. Polm. 37:123-130.

Cerning, J. 1990a. Exocellular polysaccharides produced by lactic acid bacteria. FEMS Microbiol. Rev. 87:113-130.

Cerning, J., C. Bouillananne, M. J. Desmazeaud, and M. Landon. 1988. Exocellular polysaccharide production by Streptococcus thermophilus. Biotechnol. Lett. 10:255-260.

Cerning, J., C. Bouillananne, M. Landon, and M. J. Desmazeaud. $1990 \mathrm{~b}$. Comparison of exocellular polysaccharide production by thermophilic lactic acid bacteria. Sci. Alim. 10:443-451.

Cerning, J., C. Bouillananne, M. Landon, and M. J. Desmazeaud. 1992. Isolation and characterisation of exopolysaccharides from slime-forming mesophilic lactic acid bacteria. J. Dairy Sci. 75:692-699.

Coultate, T. P. 1996. Food: The Chemistry of its Components. 3 ed. Royal Soc. of Chem. Paperbacks, Cambridge, UK.

Dave, R. I., and N. P. Shah. 1998. Ingredients supplementation effects on viability of probiotic bacteria in yogurt. J. Dairy Sci. 81:2804-2816.

De Vuyst, L., and B. Degeest. 1999. Heteropolysaccharides from lactic acid bacteria. FEMS Microbiol. Rev. 23:153-177.

De Vuyst, L., F. Vanderverken, S. Van de Van, and B. Degeest. 1998. Production by and isolation of exopolysaccharides from Streptococcus thermophilus grown in a milk medium and evidence for their growth-associated biosynthesis. J. Appl. Microbiol. 84:1059-1068.

Degeest, B., B. Janssens, and L. De Vuyst. 2001. Exopolysaccharide (EPS) biosynthesis by Lactobacillus sake 0-1: production kinetics, enzyme activities and EPS yields. J. Appl. Microbiol. 91:470-477.

Dubois, M., K. A. Gilles, J. K. Hamilton, P. A. Rebers, and F. Smith. 1956. Colorimetric method for determination of sugars and related substances. Anal. Chem. 28:350-356.

Duguid, J. P. 1951. The demonstration of bacterial capsules and slime. J. Pathol. Bacteriol. 63:673-685.

Gamar, L., K. Blondeau, and J.-M. Simonet. 1997. Physiological approach to extracellular polysaccharide production by Lactobacillus rhamnosus strain C83. J. Appl. Microbiol. 83:281-287.

Gamar-Nourani, L., K. Blondeau, and J.-M. Simonet. 1998. Influence of culture conditions on exopolysaccharide production by Lactobacillus rhamnosus strain C83. J. Appl. Microbiol. 85:664-672.

Gorret, N., J. L. Maubois, J. M. Engasser, and M. Ghoul. 2001. Study of the effects of temperature, $\mathrm{pH}$ and yeast extract on growth and exopolysaccharide production by Propionibacterium acidi-propionici on milk microfiltrate using a response surface methodology. J. Appl. Microbiol. 90:788-796.

Grobben, G. J., I. C. Boels, J. Sikkema, M. R. Smith, and J. A. M. De Bont. 2000. Influence of ions on growth and production of exopolysaccharides by Lactobacillus delbrueckii subsp. bulgaricus NCFB 2772. J. Dairy Res. 67:131-135.

Grobben, G. J., J. Sikkema, M. R. Smith, and J. A. M. De Bont. 1995. Production of extracellular polysaccharides by Lactobacil- 
lus delbrueckii spp. bulgaricus NCFB 2772 grown in a chemically defined medium. J. Appl. Bacteriol. 79:103-107.

Kailasapathy, K., D. Supriadi, and J. A. Hourigan. 1996. Effect of partially replacing skim milk powder with whey protein concentrate on buffering capacity of yoghurt. Aust. J. Dairy Technol. 51(2):89-93.

Knoshaug, E. P., J. A. Ahlgren, and J. E. Trempy. 2000. Growth associated exopolysaccharide expression in Lactococcus lactis subspecies cremoris Ropy325. J. Dairy Sci. 83:633-640.

Kojic, M., M. Vujcic, A. Banina, P. Cocconcelli, J. Cerning, and L. Topisirovic. 1992. Analysis of exopolysaccharide production by Lactobacillus casei CG11, isolated from cheese. Appl. Environ. Microbiol. 58:4086-4088.

Manca de Nadra, M. C., A. M. Strasser de Saad, A. A. Pesce de Ruiz Holgado, and G. Oliver. 1985. Extracellular polysaccharide production by Lactobacillus bulgaricus CRL 420. Milchwissenschaft 40:409-411.

Marshall, V. M., E. N. Cowie, and R. S. Moreton. 1995. Analysis and production of two exopolysaccharides from Lactococcus lactis subsp. cremoris LC 330. J. Dairy Res. 62:621-628.

Pham, P. L., I. Dupont, G. Roy, G. Lapointe, and J. Cerning. 2000. Production of exopolysaccharide by Lactobacillus rhamnosus
$\mathrm{R}$ and analysis of its enzymatic degradation during prolonged fermentation. Appl. Environ. Microbiol. 66:2302-2310.

Roberts, C. M., W. F. Fett, S. F. Osman, C. Wijey, J. V. O'Connor, and D. G. Hoover. 1995. Exopolysaccharide production by $\mathrm{Bi}$ fidobacterium longum BB-79. J. Appl. Bacteriol. 78:463-468.

Sebastiani, H., and G. Zelger. 1998. Texture formation by thermophilic lactic acid bacteria. Milchwissenschaft 53(1):15-20.

Shah, N. P., and P. Jelen. 1990. Survival of lactic acid bacteria and their lactases under acidic conditions. J. Food Sci. 55:506-509.

Torino, M. I., M. P. Taranto, F. Sesma, and G. Font de Valdez. 2001. Heterofermentative pattern and exopolysaccharide production by Lactobacillus helveticus ATCC 15807 in response to environmental pH. J. Appl. Microbiol. 91:846-852.

Uemura, J., T. Itoh, T. Kaneko, and K. Noda. 1998. Chemical characteristics of exocellular polysaccharides from Lactobacillus subsp. bulgaricus OLL1073R-1. Milchwissenschaft 58:443-447.

van den Berg, D. J. C., G. W. Robjin, and A. C. Janssen. 1995. Production of a novel extracellular polysaccharide by Lactobacillus sake 0-1 and characterisation of the polysacchride. Appl. Environ. Microbiol. 61:2840-2844.

Walstra, P., and R. Jenness. 1984. Dairy Chemistry and Physics. John Wiley and Sons, Inc., New York, NY. 